\title{
Determination of the Objectives of Motivation to Nature Training with Natural Sports Class
}

\author{
Oktay $\operatorname{Kizar}^{1, *}$, Harun Genç ${ }^{1}$, Ghazwan Karaem $\mathrm{Ali}^{2}$ \\ ${ }^{1}$ High school of Physical Education and Sports, Bingöl University, Turkey \\ ${ }^{2} 17$ Fibrayir Libya School, Ankara, Turkey
}

Copyright $\odot 2019$ by authors, all rights reserved. Authors agree that this article remains permanently open access under the terms of the Creative Commons Attribution License 4.0 International License

\begin{abstract}
The purpose of the present study was to determine the motivating reasons of the students studying at the Department of Physical Education and Sports in Bingöl University in the year 2017 in nature sports classes and in participating trekking. The questionnaire that was used in the study was applied to a total of 87 people 30 of whom were male and 57 were female who were selected with random sampling method among 260 students in 2017-2018 Academic Year in Bingöl. After the literature review for the scale to be used in the study, it was decided that the Participation in Hiking Motivation Scale (PHMS), whose validity and reliability study was conducted by Ekinci, E. in 2012, was used. To analyze the data obtained, the SSPS 22.0 Statistical Package Program was used and the data were classified. The frequency and percentage distributions were carried out with Anova and t-test. According to the results of the t-test analysis made for the data obtained from the students of Bingöl University Physical Education and Sports School, no significant differences were detected between the students in the 5 dimensions that motivated the participation of the students from teaching, training and management departments of the Bingöl University, Physical Education and Sports High School to nature sports classes and trekking activities in terms of gender. No significant differences were found between the environment where the students grew up and economic status variables $(p>0.05)$. As a result, it was determined that there were no significant differences between the social, time, education, observation and health sub-dimensions in motivating the participation of the students of the Physical Education and Sports High School of Bingöl University; it is possible to argue that social, time, education, observation and health sub-dimensions are not an important factor in motivating the participation the students to nature classes and nature sports. Applicable trainings may be included more in curricula to raise awareness on nature sports and on the environment with recreation education system and discipline to motivate students to participate in nature classes.
\end{abstract}

Keywords Nature Sports, Motivation, Participation, Hiking, Bingöl

\section{Introduction}

In making use of leisure time, sports events have an important place especially in developed countries. In parallel with the free time and sporting activities, which are one of the leisure activities, complement the social status of the individual (1). In this respect, sports should be considered as an important social phenomenon, especially because of its prevalence. With this phenomenon, we can say that sport is an occupation of leisure time with its own rules (2). On the other hand, sports are affected by the social and cultural conditions. In recent years, the changes in interest in sports activities reveal the relationship between social and cultural structures and sports activities. The interest being shifted in the understanding sportive activities Show the relation between social and cultural structures and sports activities. Traditional sports such as football, swimming wrestling, athletics; health, adventure and pride for the purpose of gliding gliders, hiking, mountaineering and so on. (3). People are interested in a variety of sports activities at leisure, depending on many reasons. One of these types of sports is nature sports. Many individuals who are separated from nature and natural life as a result of urbanization and who are doomed to live in monotonous life in the city today are taking care of nature sports by eliminating the longing for nature and integrating with nature. Nature is one of the most practical sports in nature. Nature walks can be daily, depending on the wishes of the participants, and they are carried out in the form of long walks with camps (4). Hiking is no longer included in the form of relocation of almost all modern individuals, even for the shortest routes as a leisure activity, self-proving, peace and comfort, and is felt in the context of establishing a relationship with nature (5). Going out to 
nature, seeing the serenity and cleanliness of nature causes a feeling of relief in the inner structure of the individual, and as this is repeated, the city breaks from the spirit and the return to its inner feeling begins; nature walks are a trainer that explores, introduces and teaches nature and self to people (6).

\section{Nature Sports Concept}

In particular, the increase of interest in sports as a recreational activity leads various social institutions to make organizations in this field. Schools, sports clubs, various associations and state institutions have started to organize sportive activities with no competitional purposes. A new team of sports branches such as hiking, camping, rafting has begun to come up with these organizations, so that new varieties of sports are introduced and expanded. Having a positive contribution to the physical and mental health of individuals, nature sports have an important place in terms of decreasing the effects of crowded and busy life on the people and increasing social relations among people (7). Having gained a rapid momentum in our country since the beginning of the 1980s, nature sports continue to offer different alternatives to today's people with increasing diversity (8). Outdoor sports are the sporting activities that individuals do by using their own powers and abilities without the help of motor or other vehicles in natural environments which are not changed by people. In line with the above definition, high mountain climbing, rock climbing, caving, mountain biking, orienteering, hiking, rafting, canoeing, skiing, snowboarding, parachute, paragliding, sailing, sea, river, swimming in the lake, etc. sports branches are examples of extreme sports. Activities such as motor sports are not included in nature sports. Outdoor sports are becoming more and more preferred by the urban environment in today's life, in the environments where the relations with nature are almost disappearing, between the continuous walls and the people who work in non-natural places. When we say nature sports, we can think of sports in nature. Outdoor sports, which appear before as nature sports, can be defined as the use of nature for sports purposes. Grass on the slopes all of the sports intertwined with the nature are mentioned with the name of nature sports, such as scuba diving, climbing steep cliffs and paragliding (9). Sports activities in nature have been classified under different names depending on the risk factors and auxiliary materials used like; "adventure recreation", "nature sports", and "open area recreation". A wide range of activities such as hiking, camping, fishing, canoeing, skiing, horse riding, golf, water skiing, motor sports, air sports are called open space recreation for the participants to interact with the natural environment (10).

\section{Hiking}

The benefit of hiking to human health is not just a reality that has emerged today. In the period of Anatolian Seljuk State, the book titled Tuhfe-i Mübarizi, written by Hekim Bereket, discusses the benefits of hiking in terms of health.

As far as is known, Hekim Bereket's Tuhfe-i Mübarizi (Gift for Mutual Discussion) is the first Turkish work written in Anatolia. Based on the book of Ibn Sina's Law, Physician Bereket wrote an Arabic work and then translated it into Persian, and then into Turkish. The work is 60 pages and consists of four main sections. In the first part, there is "Nature Works"; in the second part, "Works Outside Nature", in the third section, "Health Protection", and in the fourth section "Treating" (11). In the third section, "Protecting the Health", health protection such as walking, moving and being calm are mentioned (12). Similarly, one of the sayings of Hippocrates 2400 years ago is about walking. Hippocrates said: "Walking is the best medicine of man". In addition, the thing that made hiking such a perfect exercise was not it did for you, this was the thing it did not do for you. Compared to many other exercises, it is relatively purified from trauma (13), emphasizing the importance of hiking in terms of health. The current meaning of hiking is the general name of long walks in the mountainous parts of a region, without requiring climbing techniques, without entering into hard and steep places, followed by small paths, in nature conditions showing specific difficulties and features, and in time-limited and limited to age groups. Nature walks can be up to one month or daily trips (14). It is not a recreational tour, it is more than a recreational tour. It is a tourist activity. It is not like mountaineering, it is based on traveling, seeing and exceeding. Considering the history of trekking, in the 19th century, the first hiking tours were made in 1968. The first hiking organizations were organized to Nepal by Mountain Travel (American) and Hiking International (Italian) by travel companies, and then quickly developed. Anatolia hosted many unique civilizations throughout history. Therefore, the paths such as "Silk Road", "Saint Paul Road" and the "Lycian Way", which constitute an important potential. The Saint Paul Road is a 500-kilometer walking route that connects the Taurus Mountains with migration routes and paths. The most important of these is the Lycian Road. Turkey is a unique country for hiking with its climatic conditions, geographical characteristics, natural resources.

\subsection{Types of Hiking}

It is possible to classify hiking as hiking and trekking. Hiking: Day trips, long-distance, medium-level trips. If required, one-night stay can also be made (6). People of all ages can go hiking. There are many regions suitable for hiking in our country. The hiking period varies depending on the difficulty of the track. A moderate track takes approximately 5-6 hours. It is a sporting activity that people want to spend a day alone with nature and share its beauties with their friends. The aim is to ensure participation in the natural life that is missed in the city for 
a day (16). Hiking: Hiking means a few days of walking (17). According to another definition, hiking is a challenging nature walk that lasts for a few days, with tent accommodation, long-distance and ascending at places (6). The most important feature that separates hiking from trekking is the duration. In this sense, hiking is a normal day trip, but in some special cases, it takes up to two days. In hiking, this period is at least two days and may take up to several weeks. In addition, although there is accommodation in both types, these accommodations are not obligatory for hiking, while accommodation is an absolute must in trekking (16).

\section{Method}

The literature review was made and the reliability and validity studies of the measurement tool were conducted by Ekinci, E. (2012) with a sampling of 99 men (54.4\%) and 83 women $(45.6 \%)$, which made to a total of 182 trekkers. The Participation in Hiking Motivation Scale (PHMS) was applied to the participants and the factor loads were determined to be bigger than .40 and varied between .509 and .794 .

A total of 87 students, who studied at Physical Education Department in Bingöl in 2017-2018 academic year, were randomly recruited; and 30 of the participants were female, and 57 of them were male. The participants were selected from among 260 students. The literature review for the scale that was used in the study was carried out, and the Participation in Hiking Motivation Scale (PHMS) whose validity and reliability studies were conducted by Ekinci, E. (2012) was used. To evaluate the data that were obtained, the data were classified by using the SSPS 22.0 statistical package program. In evaluating the data, frequency and percentage distributions and Anova and t-test were used. No significant differences were detected between the 5 sub-dimensions motivating the participation in the nature sports class and hiking of the students of the Physical Education and Sports Department of Bingöl University in terms of the environment in which the students grew and their economic status $(\mathrm{p}>0.05)$.

This scale, which was included in the last section, is named "Participation in Hiking Motivation Scale (PHMS). This scale consisted of 46 items and 5 sub-dimensions; (1) social, (2) health, (3) education, (4) time, (5) observation; and was evaluated with 5-Point Likert Scale as; I Strongly Disagree (1), I disagree (2), "I am indecisive" (3), "I Agree" (4) and "I Strongly Agree" (5). The Scale Analysis results were examined in 5 -factor social $(1,2,3,5,11,18,20)$, health $(4,6,7,8)$, education $(9,14,15,16,17)$, time $21,22,23,24)$ and observation $(10,12,13)$ sub-dimensions. There were no significant differences between the environment when the students grew and their economic situations in the 5 sub-dimensions that motivated the participation of the students in the nature sports class and hiking of the students of the Physical Education and Sports Department of the Bingöl University $(\mathrm{p}>0.05)$.

\section{Results}

Demographic Features of the Trekking Participants

According to the results of the t-test, the Participation in Hiking Motivation Scale (PHMS) [t (87)=.619; p>.990], "health" $[\mathrm{t}(87)=.611 ; \mathrm{p}>.242]$, "education" $[\mathrm{t}(87)=.085$; $\mathrm{p}>$.771], "time" [t (87) = 1.159; $\mathrm{p}>.285]$, "observation" [t $(87)=1.195 ; \mathrm{p}>$.170] sub-dimensions did not show a significant difference according to gender.

Table 1. Participants' PHMS T-Test Results According to Genders

\begin{tabular}{|c|c|c|c|c|c|c|}
\hline Dimensions & Gender & $\mathbf{N}$ & Ort. & S.S & $\mathbf{t}$ & $\mathbf{p}$ \\
\hline \multirow{2}{*}{ Social } & Women & 30 & 4,0333 & 17452 & \multirow{2}{*}{,619 } & \multirow{2}{*}{,990 } \\
\hline & Man & 57 & 3,9035 &, 12130 & & \\
\hline \multirow{2}{*}{ Health } & Women & 30 & 4,0083 &, 15137 & \multirow{2}{*}{,611 } & \multirow{2}{*}{,242 } \\
\hline & Man & 57 & 3,7588 & ,13096 & & \\
\hline \multirow{2}{*}{ Education } & Women & 30 & 3,9400 &, 18623 & \multirow{2}{*}{,085 } & \multirow{2}{*}{,771 } \\
\hline & Man & 57 & 3,9228 & ,12513 & & \\
\hline \multirow{2}{*}{ Time } & Women & 30 & 4,1083 & ,20646 & \multirow{2}{*}{1,159} & \multirow{2}{*}{,285 } \\
\hline & Man & 57 & 4,0877 & ,12303 & & \\
\hline \multirow{2}{*}{ Observation } & Women & 30 & 3,8222 & ,19027 & \multirow{2}{*}{1,195} & \multirow{2}{*}{, 170} \\
\hline & Man & 57 & 3,7895 & ,11214 & & \\
\hline
\end{tabular}


Table 2. ANOVA Results According to the Environment where the Participants' Points Regarding the Sub-Dimensions of the (PHMS)

\begin{tabular}{|c|c|c|c|c|c|c|c|}
\hline Dimensions & $\begin{array}{l}\text { Source-of } \\
\text { Variance }\end{array}$ & KT & Sd & KO & $\mathbf{F}$ & $\mathbf{P}$ & Difference Tukey \\
\hline \multirow{3}{*}{ Social } & Between Groups & 694 & 2 & ,347 & \multirow[t]{3}{*}{,399 } & \multirow[t]{3}{*}{ 672 } & \\
\hline & Intra-Group & 73,104 & 85 &, 870 & & & \\
\hline & Total & 73,798 & 87 & 1,217 & & & \\
\hline \multirow{3}{*}{ Health } & Between Groups & 4,161 & 2 & 2,080 & \multirow[t]{3}{*}{2,436} & \multirow[t]{3}{*}{,094 } & \\
\hline & Intra-Group & 71,745 & 85 & 854 & & & \\
\hline & Total & 75,905 & 87 & 2,934 & & & \\
\hline \multirow{3}{*}{ Education } & Between Groups & 1,134 & 2 & ,567 & \multirow[t]{3}{*}{,603 } & \multirow[t]{3}{*}{, 550} & \\
\hline & Intra-Group & 79,024 & 85 & ,941 & & & \\
\hline & Total & 80,158 & 87 & 1,508 & & & \\
\hline \multirow{3}{*}{ Time } & Between Groups & ,062 & 2 & ,031 & \multirow[t]{3}{*}{, 030} & \multirow[t]{3}{*}{,753 } & \\
\hline & Intra-Group & 85,343 & 85 & 1,016 & & & \\
\hline & Total & 85,405 & 87 & 1,047 & & & \\
\hline \multirow{3}{*}{ Observation } & Between Groups & ,483 & 2 & 242 & \multirow[t]{3}{*}{,285 } & \multirow[t]{3}{*}{,970 } & \\
\hline & Intra-Group & 71,174 & 85 & 847 & & & \\
\hline & Total & 71,658 & 87 & 1,089 & & & \\
\hline
\end{tabular}

According to the results of ANOVA in Table 2, Participation in Hiking Motivation Scale (PHMS), $\left[\mathrm{F}_{(2-85)}=, 399\right.$ $\mathrm{p}>$,672], "health" $[\mathrm{F}(2-85)=2,436 \mathrm{p}>, 094$ ], "Education" $[\mathrm{F}(2-85)=.603$ p $>.550], 85$ "time" $\mathrm{F}[\mathrm{F}(2-85)=.030$ $\mathrm{p}>.753]$ and "observation" $[\mathrm{F}(2-85)=.285 \mathrm{p}>.970]$ There is no statistically significant difference between the scores of the sub-dimensions according to the environment.

Table 3. Participants' PHMS ANOVA Results According to Economic Status

\begin{tabular}{|c|c|c|c|c|c|c|c|}
\hline Dimensions & Source of Variance & KT & Sd & KO & $\mathbf{F}$ & $\mathbf{P}$ & Difference Tukey \\
\hline \multirow{3}{*}{ Social } & Between Groups & 2,848 & 2 & ,949 & \multirow{3}{*}{1,110} & \multirow{3}{*}{, 350} & \\
\hline & Intra-Group & 70,951 & 85 &, 855 & & & \\
\hline & Total & 73,798 & 87 & 1,804 & & & \\
\hline \multirow{3}{*}{ Health } & Between Groups & 2,001 & 2 & ,667 & \multirow{3}{*}{,749 } & \multirow{3}{*}{, 526} & \\
\hline & Intra-Group & 73,904 & 85 &, 890 & & & \\
\hline & Total & 75,905 & 87 & 1,557 & & & \\
\hline \multirow{3}{*}{ Education } & Between Groups & 4,315 & 2 & 1,438 & \multirow{3}{*}{1,574} & \multirow{3}{*}{,202 } & \\
\hline & Intra-Group & 75,843 & 85 & ,914 & & & \\
\hline & Total & 80,158 & 87 & 2,352 & & & \\
\hline \multirow{3}{*}{ Time } & Between Groups & 5,938 & 2 & 1,979 & \multirow{3}{*}{2,067} & \multirow{3}{*}{, 111} & \\
\hline & Intra-Group & 79,468 & 85 & ,957 & & & \\
\hline & Total & 85,405 & 87 & 2,936 & & & \\
\hline \multirow{3}{*}{ Observation } & Between Groups & 2,571 & 2 & 857 & \multirow{3}{*}{1,030} & \multirow{3}{*}{,384 } & \\
\hline & Intra-Group & 69,086 & 85 &, 832 & & & \\
\hline & Total & 80,158 & 87 & 1,689 & & & \\
\hline
\end{tabular}

According to ANOVA results in the Table 3, Social subscale scores of "Nature Walkers Motivation Scale, [F (2-85) $=1,110 \mathrm{p}>, 350]$, "health" [F (2-85) =, $749 \mathrm{p}>, 526]$,$] "education" [\mathrm{F}(2-85)=1,574 \mathrm{p}>, 202]$,$] time, [\mathrm{F}(2-85)=2,067$ $\mathrm{p}>, 111]$ and] "observation" [F $(2-85)=1,030 \mathrm{p}>, 384]$. There is no statistically significant difference between the scores of the sub-dimensions according to their economic status. 
Table 4. Participants' Nature Walk Distributions about what they heard for the first time

\begin{tabular}{|l|c|c|}
\hline Variables & f & $\mathbf{\%}$ \\
\hline Newspaper / Magazine from & 7 & 8,0 \\
\hline From Friends & 30 & 34,5 \\
\hline From Posters & 2 & 2,3 \\
\hline Radio / TV from & 18 & 20,7 \\
\hline From İnternet & 16 & 18,4 \\
\hline Other & 14 & 16,1 \\
\hline Total & 87 & 100 \\
\hline
\end{tabular}

When the variables related to where the participants first heard of nature walks were examined, at least 2 people stated their $2.3 \%$ posters, and the maximum number of people was $34.5 \%$.

Table 5. Distribution of Participants with Who to Participate in Leisure Activities

\begin{tabular}{|l|c|c|}
\hline Variables & f & $\mathbf{\%}$ \\
\hline Alone & 12 & 13,8 \\
\hline With my family & 1 & 1,1 \\
\hline With my friends & 70 & 80,5 \\
\hline My relatives & 4 & 4,6 \\
\hline Total & 87 & 100 \\
\hline
\end{tabular}

When the variables related to the participants' participation in activities in their spare time were examined, it was determined that 12 people participated in activities with $13.8 \%$ alone, 1 person with $1.1 \%, 70$ persons with $80.5 \%$ friends and 4 people with $4.6 \%$ relatives.

Table 6. Distribution of Participants Generally About Leisure Time

\begin{tabular}{|l|c|c|}
\hline Variables & f & \% \\
\hline Joining Physical Activities & 16 & 18,4 \\
\hline Participating in Social Activities & 32 & 36,8 \\
\hline Participating in Cultural Events & 3 & 3,4 \\
\hline Attending Artistic Events & 6 & 6,9 \\
\hline Participating in Touristic Activities & 6 & 6,9 \\
\hline Relax & 17 & 19,5 \\
\hline Other & 7 & 8,0 \\
\hline Total & 87 & 100 \\
\hline
\end{tabular}

When we look at the variables about how participants evaluate their free time, 18 people participating in physical activities, $18.4 \%$ in social activities, $36.8 \%$ in social activities, 3 in cultural events, $3.4 \%$ in cultural activities, 6 in artistic activities, $6.9 \%$ in tourism 6 people who participated in the activities, $6,9 \%, 17$ people $19,5 \%$, 7 people participated in the $8.0 \%$ were found to participate.

\section{Discussion and Conclusions}

In this study, it was determined that there is a significant difference according to the points of 5 sub-dimensions related to social, health, education, time and observation motivating the participation of the students in the department of teaching, coaching and management in Bingöl University Physical Education and Sports College with the nature sports course intended.

In our study, when we look at the variables of how often they evaluate leisure time 36 of the participants $(36.8 \%)$ stated that they had attended social activities in their free times. In a different study, when the variables of how often they evaluate leisure time by trekkers, $48.7 \%$ of the participants stated that they spent their free time participating in social activities (18). In the study carried out on the participation in nature sports, it was determined that what aspect of nature sports is important was preferred by social aspect (44.8\%). In addition, it is understood that Erturan and Sahin, in their study on outdoor sports organizations at universities, considered the participants as a social environment $1(21.3 \%)$ as a priority (20). These results are similar to our study. As a result of the findings, we can say that the participants want to participate in walks as a group instead of participating in nature activities. One of the possible benefits of group marches is solidarity. In the group march, vitality, different conversations and exchange of ideas, especially and above all, bring together an association, community spirit, cooperation, efficient competition, small ones, weaknesses, self-organized organizations designed to protect those who are injured (5). One of the findings obtained from different studies by Aydoğan and Aral in the study conducted on university students' leisure time assessment, nearly half of the students (47.1\%) (21). In the study conducted by Arıkan and Özkökeli about the leisure activities of the students of the Police Academy, it was found that academy students spent their free time listening to music (36\%) (22). In addition, Özdilek et al. conducted a study on university students in Dumlupinar and Sakarya universities. Similarly, Soyer and Can's study on university students revealed that almost half of the participants preferred sport activities (40.8\%) (24).

By looking at these studies, we can say that the variables related to how individuals and students generally evaluate leisure time differ in personality, education styles and social status. According to the variables, $(80.5 \%)$ attended the leisure activities. In a study conducted in Ankara province, the ratio of the participants $(45 \%)$ with the "friends" variable is higher than the other three variables (18). The study carried out by Güngörmüş on the individuals taking care in the private health sports centers (25) is similar to the studies carried out by Ardahan and Lapa on bicycle users and hikers (26) and Çolakoğlu and Yenel on university students (27). In a study conducted by Soyer and Can on university students, it was determined 
that a large proportion of the participants participated in leisure activities with their friends (67.7\%) (28). As a result of these findings it can be said that the students prefer to participate in leisure activities with their friends. There is a significant relationship between the reasons for participation in outdoor activities and who they participate with. In the studies conducted, it was concluded that the individuals were more likely to participate in outdoor activities with their friends and friends, and they were not in a lot of activities with their family, spouses, school or colleagues. Open space to be with family (29). In addition to those who prefer recreation activities, the desire to stay away from family is said to be a determining factor in participation in activities (26).

When we look at the variables of the nature walkers' where they first heard nature walks, it is seen that from my friends $(36.8 \%)$. In a study conducted in the province of Ankara, it was found that the "friends" option (52.3\%) preferred the highest rate compared to the other four options. As a result of these findings, it is understood that friend option is more effective than "newspaper / magazine", a poster radio / tv and internet. It is stated that voluntary sport base unions that make arrangements for walking are not able to use mass transmission vehicles effectively and this situation is interpreted as negatively affecting the number of individuals participating in nature walks and the number of activities (18). According to the results of t-test, it was determined that there was no significant difference between the subscales of the Nature Walk Participation Motivation Scale ( $p>.170)$. Ekinci, E. 's 2012 in Ankara province in the study of nature hiking heredity was found a significant difference according to gender. This study is not similar to the findings of our study. According to the ANOVA results in Table 2, it is seen that there is no statistically significant difference between the scores of the trekkers on the sub-dimensions of the Participation Motivation Scale of the Participation Motivation Scale ( $>$ 970). In a study performed in Ankara ( $>$.258), it was similar to our study that there was no statistically significant difference between the subscale scores of the study (18). The most important condition for accessing environmental consciousness is the fundamental change in the social behavior of the individual. This is only possible with an effective and comprehensive nature (environment) education (30). The roots of nature (environment) education are based on education of protecting nature and natural resources (31). It is the main objective of environmental education to inform all sections of the society about the environment, to gain positive and lasting behavioral changes and to ensure the active participation of individuals in solving the problems (32). Nature education is different from the typical education process. Nature (environment) education provides participants with a strong motivation to participate in events and also provides environments and activities where decision-making, teamwork, interpersonal communication and problem-solving skills are required. They include entertainment and games. In nature (environment) education, participants are able to assess what their capacities are, to be strong, to be self-sufficient and to find opportunities for cooperation (33).

According to the ANOVA results in Table 3, it is seen that there is no statistically significant difference between the scores of the Participation Motivation Scale of Nature Walkers subscale scores of the Social subscale scores ( $p>$, 384). Ekinci, E. (p>, 526) in 2012 in his study of the subscales of the scores related to their economic status did not find a statistically significant difference (18). This is similar to our study. We can say that there is no direct factor in the economic status of the students studying in the departments of teaching, coaching and management at the Physical Education and Sports Department.

As a result, it was determined that there were no significant differences between the social, time, education, observation and health sub-dimensions in the motivations of the students of the teaching, training and management Department of the Physical Education and Sports of Bingöl University. It is possible to argue that social, time, education, observation and health sub-dimensions are not important factors in motivating the participation of the students to nature classes and nature sports. Applicable trainings may be included more in curricula to raise awareness on nature sports and on the environment with recreation education system and discipline to motivate students to participate in nature classes. Awareness on nature sports can be provided by giving more practical training to the students about the development of environmental awareness with the nature education system and discipline. In this way, many people, who are doomed to live a monotonous life with technology being too much in life especially in cities, along with the culture of urbanization, apart from nature and natural life, will be directed to individual sports like gliding, trekking, mountaineering and so on as well as traditional sports like football, swimming, wrestling, athletics, deal with nature sports and take pleasure in nature sports by taking a look at the nature of sports and also enjoy the happiness of being away from the habitual level of life even for a moment, and will satisfy their longing for nature and integrate with it.

\section{REFERENCES}

[1] Erkal E, Güven Ö, Ayan D. Sosyolojik Açıdan Spor. 3. Baskı. İstanbul: Der Yayınları; 1998.

[2] Doğan B. Spor Sosyolojisi ve Uygulamalı Spor Sosyolojisine Giriş. 1. Baskı. Ankara: Nobel Yayınevi; 2007.

[3] Karaküçük S. Rekreasyon ve Dağcılığın Rekreasyon Olarak Değeri. 1. Yüksek İrtifa ve Spor Bilimleri Kongresi Bildiriler Kitabı. Kayseri: 30 Ekim - 02 Kasım 1991; 99 103. 
[4] Doğan B. Spor Sosyolojisi ve Uygulamalı Spor Sosyolojisine Giriş. 1. Baskı. Ankara: Nobel Yayınevi; 2007.

[5] Le Breton D. Yürümeye Övgü. (Yerguz İ. Çev.). 2. Bask1. İstanbul: Sel Yayıncılık; 2008.

[6] Şahin K. Z. Doğada Yapılan Yürüyüşler Hiking \& Hiking. İstanbul: Dijital Sanat Yayıncılık; 2010.

[7] Yılmaz B. Doğa Sporlarına Katılımın Sosyal Bütünleşmeye Etkisi. Doktora Tezi. Ankara: Gazi Üniversitesi; 2006.

[8] Doğa Sporları ve Doğa Aktiviteleri Kataloğu. Ankara: Dörtrenk Yayın Tanıtım; 2006.

[9] Uğurlu A. Rekreasyonel Amaçlı Doğa Sporlarının Turizm'de Kullanılması Antalya Köprülü Kanyon Rafting Uygulamas1. Yüksek Lisans Tezi. Antalya: Akdeniz Üniversitesi; 2005.

[10] Koçak F, Balcı V. Doğada Yapılan Sportif Etkinliklerde Çevresel Sürdürülebilirlik, Ankara Üniversitesi Çevre Bilimleri Dergisi 2010; 2(2): 213-222.

[11] Yurdakök M. Tuhfe-i Mübarizi'de Çocuk Hekimliği Bilgileri. Çocuk Sağlığı ve Hastalıkları Dergisi 2004; Sayı 47: 233- 236.

[12] Derin A. Tuhfe-i Müharizı: Metin - Gramer Notları - Sözlük. Yüksek Lisans Tezi. Ankara: Gazi Üniversitesi; 1987.

[13] İri R. Yürüyüş Egzersizinin 18-22 Yaş Arası Bayanların Bazı Fiziksel ve Fizyolojik Parametrelere Etkisi. Yüksek Lisans Tezi. Kütahya: Dumlupınar Üniversitesi; 2007.

[14] Erdoğan N. Çevre ve (Eko)turizm. Ankara: Erk Yayınları; 2003.

[15] Yarcan Ş. Seyahat Yönetimi. 1. Bask1. İstanbul: Boğaziçi Üniversitesi Yayınları; 1993.

[16] Doğa Yürüyüşü [İnternette]. [Erişim Tarihi 12.07.2011]. http://www.dogakolik.com/index.php?topic=78.0.

[17] Özdemir A. S. Türkiye Taş Kömürü Genel Müdürlüğünde Çalışan Yer Altı İşçilerinin Boş Zamanlarını Değerlendirme Alışkanlıklarının Belirlenmesi. Yüksek Lisans Tezi. Ankara: Gazi Üniversitesi; 2006.

[18] Ekinci, E. Bireyleri Doğa Yürüyüşlerine Katılıma Motive Eden Nedenlerin Belirlenmesi: Ankara Örneği, Yüksek Lisans Tezi, Ankara 2012. s.90.

[19] Doğa Sporları ve Doğa Aktiviteleri Kataloğu. Ankara: Dörtrenk Yayın Tanıtım; 2006.

[20] Erturan E. E, Şahin M. Y. Üniversitelerdeki Doğa Sporları Örgütlerinde Üyelerin Katılım Nedenleri ve Beklentilerinin Tespiti Üzerine Bir Araştırma (Güdak Örneği). 1. Gençlik Boş Zaman ve Doğa Sporları Sempozyumu Bildiriler Kitabı. Ankara: 21-22 Mayis 2003; 174-186.

[21] Aydoğan Y, Aral N. Ankara Üniversitesi Ev Ekonomisi Yüksekokulu Öğrencilerinin Boş Zamanlarını Değerlendirme Durumlarının İncelenmesi. Milli Eğitim Dergisi [Düzenli Elektronik Dergi] 2007 - Kış. [01.04.2012]; Say1 173 [Ekran Sayıs1 1]. http://dhgm.meb.gov.tr/yayimlar/dergiler/Milli_Egitim_De rgisi/ 173/173/09.pdf

[22] Arıkan Y, Özkökeli N. Polis Akademisi Öğrencilerinin Boş
Zaman Faaliyetleri Üzerine Bir Araștırma. Polis Bilimleri Dergisi 2002.4 (1-2); 157-170.

[23] Özdilek Ç, Demirel M, Harmandar D. Dumlupınar ve Sakarya Üniversitelerinde Öğrenim Gören Beden Eğitimi ve Spor Yüksekokulu Öğrencilerinin Boş Zaman Etkinliklerine Katılım Nedenleri ve Düzeylerinin Karşılaştırılması. Uluslararası İnsan Bilimleri Dergisi 2007. 4 (2); 1-13.

[24] Soyer F, Can Y. Üniversite Öğrencilerinin Boş Zaman Alışkanlıkları ve Sportif Eğilimlerinin Mesleki Yönelişlerine Göre Karşılaştırılması. 1. Gençlik Boş Zaman ve Doğa Sporları Sempozyumu Bildiriler Kitabı. Ankara: 21-22 Mayis 2003; 102-120.

[25] Güngörmüş H. A. Özel Sağl1k-Spor Merkezlerinden Hizmet Alan Bireyleri Rekreasyonel Egzersize Güdüleyen Faktörler. Doktora Tezi. Ankara: Gazi Üniversitesi; 2007.

[26] Ardahan F, Lapa T. Y. Açık Alan Rekreasyonu: Bisiklet Kullanıcıları ve Yürüyüşçülerin Doğa Sporu Yapma Nedenleri ve Elde Ettikleri Faydalar. Uluslararası İnsan Bilimleri Dergisi 2011. 8 (1); 1327-1341.

[27] Çolakoğlu T, Yenel İ. F. Üniversite Öğrencilerinin Orienteering Sporuna Katılım Nedenleri ve Beklentileri Üzerine Bir Araștırma. 1. Gençlik, Boș Zaman ve Doğa Sporları Sempozyumu. Ankara: 21-22 Mayıs 2003; 146-155.

[28] Soyer F, Can Y. Üniversite Öğrencilerinin Boş Zaman Alışkanlıkları ve Sportif Eğilimlerinin Mesleki Yönelişlerine Göre Karşılaştırılması. 1. Gençlik Boş Zaman ve Doğa Sporları Sempozyumu Bildiriler Kitabı. Ankara: 21-22 May1s 2003; 102-120.

[29] Gençay S. Gençay Ö. A, Marangoz İ, Tekerek M. Üniversite Ögrrencilerinin Rekreatif Aktivite Programlarına Katılımını Etkileyen Faktörler Üzerine Bir Araştırma: Sütçü İmam Üniversitesi Örneği. 1. Gençlik Boş Zaman ve Doğa Sporları Sempozyumu Bildiriler Kitabı. Ankara: 21-22 May1s 2003; 95-101.

[30] Yıldız K, Sipahioğlu Ş, Yılmaz M. Çevre Bilimi. 2. Baskı. Ankara: Gündüz Eğitim ve Yayıncılık; 2005.

[31] Aydoğdu M, Gezer K. Çevre Bilimi. Ankara; Anı Yayıncılık. 2006.

[32] Kurgun E, Tarkay N, Aydın N. Çevre El Kitabı. 3. Baskı. Ankara: Çevre ve Orman Bakanlığı Yayınları; 2004

[33] Çelebi M, Alkurt S.Ö, Doğu G. Yönetici Yetiştirmede Farklı Bir Yaklaşım: Rekreasyon ve Doğa Eğitimi. 1. Gençlik Boş Zaman ve Doğa Sporları Sempozyumu Bildiriler Kitabı. Ankara: 21-22 Mayıs 2003; 25-32. 